\author{
Grażyna Szyling \\ Uniwersytet Gdański \\ pedgs@ug.edu.pl
}

\title{
Ukryte w języku aspekty przygotowania dzieci do szkoły
}

\section{Summary \\ Hidden-in-language aspects of children's preparation for school}

In this paper I reconstruct the image of school generated by children a short while before they cross their first educational threshold. I am interested in the aspect of school readiness hidden in language, which is anchored in culture, social life and children's experiencing of the world.

The theoretical basis for the conducted analyses is the linguistic theory also known as the SapirWhorf hypothesis, which is complemented by the psychological concept of cognitive schemata and their role of in the process of discovering reality. The data was collected through group interviews conducted with kindergarten children focused on the issue.

The language image of the schools' world generated by children and reconstructed in the analysis conforms to the concept of transmissive education dominating in the Polish society, which positively values blind obedience and observance of other people's instructions as the strategy of learning. The paradox is that the cognitive schemata that the children have been equipped with are suitable for what is demanded of them at the stage of early education. Their impact paralysing the development of a person can only be seen when the perspective is changed and "the school is thought of differently".

Słowa kluczowe: językowy obraz szkoły, nadawanie znaczeń, dzieci przedszkolne, gotowość szkolna, edukacja transmisyjna, ograniczanie rozwoju

Keywords: language image of school, assigning of meanings, kindergarten children, school readiness, transmissive education, limitation of development

Kwestia przygotowania dziecka do edukacji szkolnej jest w Polsce powszechnie sprowadzana do normalizacyjnych procedur, w których dominują mierzalne wskaźniki, nabierające w potocznym odbiorze cech obiektywnej prawdy (Żytko 2014). Poza obszarem takich systemowych diagnoz znajduje się dziecięce postrzeganie świata szkoły i nadawane mu znaczenia, choć psycholodzy i pedagodzy od dawna zwracają uwagę na rolę, jaką w konstruowaniu przez pierwszoklasistów strategii radzenia sobie z nowym środowiskiem odgrywają posiadane przez nich schematy poznawcze. Umożliwiają one dziecku nie tylko kierowanie swoim postępowaniem tak, by unikać porażek i osiągnąć sukces szkolny (Appelt 2005), ale też pozwalają zrozumieć otaczającą go rzeczywistość i swoją w niej rolę. 
Zarysowany kontekst wyznacza najbardziej ogólny kierunek analiz wypowiedzi przedszkolaków, które zostaną pojęte w niniejszym tekście. Zamierzam na podstawie uzyskanych wyników zrekonstruować elementy schematu poznawczego szkoły, w jaki zostają wyposażone dzieci zanim przekroczą pierwszy próg edukacyjny. Interesuje mnie przy tym ukryty w języku przedszkolaków ten aspekt gotowości szkolnej, który jest zakotwiczony nie w normach rozwojowych, ale w kulturze, życiu społecznym i dziecięcym doświadczaniu świata. Stanowić on będzie bazę do refleksji nad praktyką edukacyjną, kierowanej pytaniem: Do jakiego bycia, w jakiej szkole są przygotowane dzieci?

\section{Przesłanki teoretyczne}

Podstawowej przesłanki teoretycznej dla niniejszych analiz dostarcza teoria lingwistyczna powszechnie przytaczana w literaturze przedmiotu, a znana pod nazwą hipotezy Sapira-Whorfa. Najbardziej ogólnie zakłada ona, że ludzie ,żyją w świecie zapośredniczonym językowo", a zawarte w języku sądy o świecie i stereotypy mają moc eksponowania lub ukrywania pewnych cech rzeczywistości (Klimczuk 2013: 168). Tak sformułowana hipoteza nie pozwala pominąć ideologicznego wymiaru języka, który kształtuje widzenie oraz interpretowanie świata. Magazynując i przekazując normy postępowania, wartości oraz oceny, język oddziałuje na postawy przyjmowane wobec rzeczywistości (Anusiewicz 1994: 28). Co więcej, nie tylko on zależy od kultury, której jest składnikiem, ale także ona jest „uwarunkowana tym typem języka, w obrębie którego [...] powstała, rozwinęła się i funkcjonowała" (Anusiewicz 1994:20). Zatem utrwalone w językowym obrazie świata (JOS) wiedza, doświadczenie i wartościowanie rzeczywistości nie tyle ją odzwierciedlają, ile zakreślają granice jej poznania, a nawet ją wytwarzają.

Zjawisko to jest uwikłane w złożone relacje z procesem socjalizacji. Wpisane jest weń wywieranie presji społecznej na jednostkę, najczęściej tego nieświadomą, a czasami - jak w przypadku dzieci - podatną na narzucanie znaczeń. Nie oznacza to jednak, jak twierdzi D. Klus-Stańska (2004), że dzieci stają się biernymi wykonawcami ról społecznych. Nieustannie konstruują one swoją wiedzę o otaczającej je rzeczywistości i o sobie:

Rzeczy i sytuacje, z którymi dziecko się styka po raz pierwszy, nie są po prostu białą plamą, czekającą na ,poprawne” zdefiniowanie przez kogoś, „kto już to zna”. [...]. Konstrukty znaczeniowe, jakie wytwarza, są zindywidualizowane - choć ulokowane w polu kulturowej wspólnoty znaczeń i adekwatności praktycznej [...]. Zawsze jednak są wynikiem mentalnej negocjacji znaczeń wynikających z doświadczania świata poprzez jego obserwację, działanie w nim i uczestniczenie w procesach komunikacji (tamże: 18).

Owo uczestniczenie w procesach komunikacji oznacza między innymi, że język używany wobec dzieci jest w rezultacie używany także przez nie. Dzieje się tak, ponieważ dorośli dominują w interakcjach z dziećmi, uznając, że posiadają więcej niż one kompetencji czy wiedzy o danym obszarze rzeczywistości (Stemplewska-Żakowicz 2002:106). W takiej 
sytuacji wagi nabiera określenie zewnętrznego kontekstu, w jakim dziecko konstruuje swój obraz świata, oraz ustalenie, kto wyznacza reguły komunikacji i kto mówi. Internalizowane przez dzieci znaczenia są bowiem tylko początkowo otwarte na modyfikacje, natomiast w miarę ich potwierdzania utrwalają się i układają we względnie spójny osobisty model danej rzeczywistości, z czasem coraz bardziej wieloaspektowy (Klus-Stańska 2004: 20).

$\mathrm{W}$ tak rozumianym procesie poznawania znaczącą rolę odgrywają schematy poznawcze, które dostarczają uogólnionej wiedzy o pewnym fragmencie rzeczywistości oraz reguł jej intepretowania obowiązujących w obszarze określonej kultury. Schemat może być utożsamiany ze stereotypem, który jednostronnie ukierunkowuje uwagę i myślenie jednostki, pozbawiając je elastyczności i utrudniając działanie w nowych warunkach. Może też być rozumiany - zgodnie z psychologią kognitywną - jak aktywna struktura poznawcza, wzbudzająca w umyśle jednostki pewne oczekiwania, które ta chce potwierdzić, dążąc do znalezienia stosownych informacji w otaczającej ją rzeczywistości. Jeśli poznawany świat nie dostarczy alternatywnej hipotezy lub informacji niezgodnych ze zaktywizowanym schematem poznawczym, ten się utrwala (Trzebiński 2002: 18-21). Schemat pozwala jednostce w sposób zrozumiały dla siebie zinterpretować określony obszar swojego życia i zrozumieć fakty społeczne dane w osobistym doświadczeniu. Jeśli zaś odnosi się do zdarzeń przyszłych, jak w przypadku schematu szkoły wytworzonego przez przedszkolaków, wiąże się z przewidywaniem i projektowaniem biegu zdarzeń, w których dziecko osadza się w roli uczestnika (tamże: 23-25). Badania wskazują przy tym, że dzieci potrafią wyjść poza myślenie w kategoriach „tu i teraz”, rozpatrywać różne możliwości oraz poznawać reguły, jakimi kierują się otaczający ich ludzie (Gopnik 2010).

Zespół schematów posiadanych przez jednostkę tworzy warunki do radzenia sobie przez nią z problemami powtarzającymi się $\mathrm{w}$ danej sferze życia, na przykład $\mathrm{w}$ byciu uczniem szkoły. W ujęciu społecznego konstruktywizmu można mówić o „kolektywnych opowieściach"(Stemplewska-Żakowicz 2002: 92), które kreują zbiorowo uzgodnioną rzeczywistość i konstytuują tożsamość grupy. Dostarczają one między innymi „wzajemnie zrozumiałych i akceptowanych wyjaśnień zachowań poszczególnych jej członków, a także aprobowanych programów działania, wynikających z narracyjnie rozumianej roli społecznej danej jednostki [...]” (tamże: 92). Miejscem wytwarzania „kolektywnych opowieści” o szkole, znaczących dla sposobu funkcjonowania instytucji edukacyjnych, jest między innymi przedszkole. W nim dziecko przygotowuje się systemowo do pełnienia społecznej roli ucznia i poznaje ramy wymagań, które będzie stawiała mu szkoła. Szczególne nasilenie działań budujących „gotowość szkolną” i opowieści o tym, co czeka dzieci w najbliższej przyszłości, następuje w roku poprzedzającym przekroczenie przez nie pierwszego progu edukacyjnego (np. Mendel, Cieślak 2009: 234-235). Badania wskazują, że to właśnie w przedszkolu dzieci uzyskują najwięcej danych, które później wykorzystują do kreowania własnych schematów nauczycieli (Appelt 2005: 281-283). Także tam zostają wyposażone w podstawowe skrypty ${ }^{1}$ zachowań pożądanych przez dorosłych w instytucjach edukacyjnych (zob. Gawlicz 2014).

1 Skrypt rozumiem tutaj - za psychologami - jak rodzaj schematu, który obejmuje informacje o zdarzeniach i działaniach oraz ich kolejności, o uczestnikach scenki i typowych obiektach w niej występujących, 


\section{Założenia metodologiczne}

Dotychczasowe rozważania uzasadniają zasady doboru próby badawczej, którą tworzą dzieci uczęszczające do przedszkola w miesiącach bezpośrednio poprzedzających przekroczenie przez nie pierwszego progu edukacyjnego. Przedmiot badań, jakim są znaczenia nadawane przez przedszkolaków szkole, dobrany jest ,rozważnie”, ponieważ odwołuje się do aspektów życia ważnych dla dzieci w tej grupie wiekowej (zob. Wiśniewska-Kin 2016: 66), choć znanych im głównie z przekazów osób znaczących oraz komentarzy do sytuacji edukacyjnych doświadczanych przez nie w przedszkolu. Niemniej ograniczony dobór próby pozwala jedynie na zarysowanie zagadnienia, a orientacja badawcza, wpisana w paradygmat interpretatywny, nie uprawnia do uogólnień.

Do gromadzenia danych posłużono się metodą wywiadu grupowego zogniskowanego na problemie ${ }^{2}$, zwanego wywiadem fokusowym (Kvale 2010; Gawlik 2012; Lisek-Michalska 2013). O jej wyborze zadecydowały pozytywne efekty grupowe, a zwłaszcza stworzenie rozmówcom poczucia bezpieczeństwa oraz warunków do interakcji i wzajemnego stymulowania się podczas rozmowy.

Podstawę rozważań tworzą wywiady z 3 grupami przedszkolaków, podczas których prowadząca je studentka systematycznie aktywizowała schemat szkoły, zachęcając dzieci do zestawienia go z doświadczeniami przedszkolnymi. Część z ujawnionych w ich analizie kategorii zestawię na zasadzie triangulacji (Flick 2011) z analogicznymi kategoriami wyodrębnionymi w 4 wywiadach, które schematu szkoły nie aktywizowały, choć dotyczyły pojęć dla niego charakterystycznych. Dzięki temu zgromadzone dane mogę traktować jak rodzaj antycypowanej wiedzy o szkole wspólnie wytworzonej przez grupę, konstruującą wspomnianą już „kolektywną opowieść”. Jest ona zakotwiczona tyleż w osobistych doświadczeniach edukacyjnych przedszkolaków, co w działaniach osób znaczących i sytuacjach komunikacyjnych z ich udziałem. Umożliwia to odczytanie wyników badań także przez pryzmat teoretycznych koncepcji szkoły, do jakich - niekoniecznie świadomie odwołują się dorośli.

W analizie treści wywiadów skupiam się na rekonstrukcji znaczenia (zob. Kvale 2010: 171-178), nadawanego przez dzieci elementarnym pojęciom związanym ze szkołą jako środowiskiem, w którym uczeń przyjmuje pewne role. Zwracam przy tym uwagę na pojawiające się w wypowiedziach badanych wartościowanie oraz stereotypowe cechy charakteryzowanych przez nie obiektów, ponieważ dostarczają one ,informacji redundantnych, na podstawie których badacz może ustalić utrwalone kulturowo sądy, skojarzone z danym pojęciem" (Wiśniewska-Kin 2016: 67).

a także o warunkach wprawiających w ruch następstwo zdarzeń i ostatecznych wynikach danego ciągu działań. Służy on nie tylko do przetwarzania informacji i jej zrozumienia, ale także zawiera w sobie sposób postępowania jednostki w danej sytuacji (Wojciszke 2000: 30-31).

2 Wywiady we współpracy ze mną przeprowadziły w kwietniu i maju 2016 roku studentki pedagogiki wczesnej edukacji, Aleksandra Lipska i Sylwia Roicka. Badania objęły 7 sześcioosobowych grup przedszkolaków z 3 przedszkoli. 


\section{Szkoła jako przestrzeń (roz)poznana}

Przedszkolaki wiedzą coś o szkole z okazjonalnych wizyt i opowieści bliskich im osób, więc są skłonne uznawać ją za przestrzeń $\mathrm{w}$ jakimś zakresie poznaną:

Wszyscy byliśmy [w szkole] $i$ nawet robiliśmy sami pracę.

Byłam. Mój brat chodzi do szkoły i czasem go odbieram z mama.

Ja wiem od mojej mamy. Ja od rodziców też wiem. pani mówita.

Co więcej, miejsce to wydaje się im na tyle oczywiste, że w odruchowej odpowiedzi na pytanie o różnice między przedszkolem i szkołą, odpowiadają, że nie dostrzegają żadnych. Dopiero zachęcane przez studentkę moderującą rozmowę, zaczynają wymieniać to, co jest inaczej w przestrzeni, którą rozpoznali z zewnątrz i w tej, którą znają dzięki codziennemu doświadczeniu. Głównym atrybutem różnicującym miejsca, w których prowadzone są zajęcia przedszkolne i szkolne, okazują się wielokrotnie wymieniane ławki:

Lawki sa. Bo tam sq ławki, a tu sq stoliki. Bo tam sq większe, a u nas mniejsze [ławki].

Tak w ogóle to raczej my mamy większe, a oni maja mniejsze, bo na dwie osoby, a u nas na sześć.

Warto zwrócić uwagę, że dla dzieci ławka szkolna ma nieco inny zakres znaczeniowy niż przedszkolny stolik, nawet jeśli ten jest nazywany przez nie również ławką. Decyduje o tym cel jej umieszczenia w klasie:

[...] bo nie wolno zmieniać tawek, trzeba usiaść w takim samym miejscu.

W klasie się siedzi i na przerwy można iść.

Nie może wyjść ze sali podczas lekcji, tylko jak jest przerwa.

Dyscyplinujący wymiar klasy szkolnej, z dominującą w jej wyposażeniu ławką, zostaje przez przedszkolaki przeciwstawiony przerwie międzylekcyjnej, która jest przez nich kojarzona z głównie z zabawą i - rzadziej - z jedzeniem:

No w szkole nie będziemy się bawić. Czasem na przerwie można.

Można, kiedy jest przerwa, iść na obiad, jeść obiad.

Wskazane cechy przerwy szkolnej sprawiają, że - mimo pewnej odrębności semantycznej - staje się ona dla dzieci rodzajem łącznika między dwoma światami: znanym z doświadczenia i nowym, ledwie rozpoznanym osobiście, w który dopiero wkroczą:

[...] że wlaśnie w szkole przerwy sa krótkie, a w przedszkolu sa duże przerwy. Sa wtedy, kiedy jest zabawa, kiedy możemy się bawić wtedy, kiedy na przykład jest rysowanie. 
Poza tym jedynym dostrzeganym wprost przez badanych zakotwiczeniem w przedszkolu, szkoła jest dla nich przestrzenią składającą się z braków, które - podobnie jak cechy przerwy - lokują oni przede wszystkim w obszarach jedzenia i zabawy:

No bo tam nie ma jedzenia, trzeba samemu sobie przynieść.

[...] a w szkole nie ma zabawy, sa komputery i krótkie positki.

W przedszkolu sa zabawki a w szkole nigdzie nie ma. I nie ma misiów.

Co więcej, zabawa staje się w szkole czymś zakazanym. Dzieci często podkreślają, że do szkoły nie można przynosić zabawek.

To wykluczenie zabawy z kręgu dziecięcego myślenia o szkole, jako instytucji, w której przedszkolaki mają kontynuować swoją edukację, jest podstawą skonstruowania kolejnej kategorii wyłonionej $w$ analizie. Jej trzon znaczeniowy tworzy opozycja między zabawą i uczeniem się, które ma zająć jej miejsce w życiu dziecka.

\section{Uczenie się w szkole i w przedszkolu}

Zaktywizowany przez studentkę, prowadzącą rozmowę z przedszkolakami, schemat szkoły sprawia, że $\mathrm{w}$ ich odpowiedziach uczenie się jest silnie powiązane $\mathrm{z}$ tą instytucją i w znacznej mierze jest czynnością semantycznie odmienną od znanej im z przedszkola. Jako pierwsze skojarzenia z tym pojęciem nasuwają się dzieciom: odrębność od zabawy i przypisanie uczenia się do konkretnych przedmiotów szkolnych:

Bo w szkole się odrabia matematyke, fizyke, przyrode, też jest pani od angielskiego, a w przedszkolu można się pobawić i też można porysować.

Równie oczywiste są dla przedszkolaków szkolne atrybuty uczenia się, które wymieniają prawie bez namysłu:

Plecaki. Torby. Ksiązki. Piórnik. Zeszyty. Kredki i pisaki. Otówek. I też będzie potrzeba gumek do zmywania.

Rzadziej natomiast dzieci wskazują w tym kontekście na komputery, telefony i tablety. Tę wiedzę zyskują głównie od starszego rodzeństwa i czerpią z okazjonalnych wizyt w szkole.

Uczenie się jest w wywiadach najczęściej kojarzone z takimi rodzajami umiejętności, których dzieci dopiero mają się nauczyć, ponieważ albo ich nie opanowały w przedszkolu, albo są one w ich mniemaniu zastrzeżone dla szkoły:

Czytać. Może jakieś dziecko nie umie pisać literek - to literek. Trzeba nauczyć się pisać, trzeba umieć trzymać mazak jak ktoś nie umie, i trzeba kredka też po śladach robić i trzeba robić bardzo dużo zadań. 
I w domu té trzeba się uczyć. Prace domowe trzeba robić.

[...] kto zrobi źle dostaje jedynkę albo dwójkę albo idzie do kąta. Albo trójkę też.

W przytoczonych fragmentach wypowiedzi dostrzec można dwa aspekty znaczeń wiązanych przez dzieci z uczeniem się w szkole. Pierwszy wskazuje wprost na wartościowanie uczenia się jako czegoś, co jest obowiązkiem i co „trzeba” wykonać. Drugi natomiast wpisuje to pojęcie w obszar oceniania i opresji, dlatego nie pozwala odczytać owego „trzeba” w kategoriach niezbędności dla jednostki, ale przesuwa pole skojarzeń w stronę przymusu, posłuszeństwa i podporządkowania. Przykładów uzasadniających ten wniosek dostarczają również inne wypowiedzi dzieci związane z uczeniem się:

Trzeba się dobrze uczyć. Stuchać się pani.

I trzeba dobrze wykonywać zadania, bo jak nie, to od nowa trzeba robić.

[...] Jak ktoś źle zrobi, to dostanie jedynkę. Albo dwójkę. A kto zrobi dobrze pracę, dostanie dobra ocene, na przyktad 6.

Przedszkolaki są przekonane, że cechą sytuacji szkolnego uczenia się jest indywidualne działanie, które wyklucza współpracę z kolegami na lekcji. Chórem odpowiadają, że nie można współdziałać z koleżanką lub kolegą z ławki, tylko robić zadania samemu. Wyjątki od tej zasady są także ściśle określone:

Każdy ma swoje książi i swój zeszyt. Trzeba samemu robić zadanie, bo jak się nie będzie miało, to pani może wstawić pałę. Ale czasem można coś powiedzieć do koleżanki.

Nie, nie pomaga się. Nie wolno. A jak się skończy, to można pomagać.

Chyba, że ktoś czegoś zapomniat, to można pożyczyć.

W tym kontekście pole znaczeniowe uczenia się zostaje zabarwione samotnością zmagań i izolacją od rówieśników. Również inne dziecięce wypowiedzi wiążą je z kulturą ciszy i (ponownie) podporządkowania:

Trudno się uczy. Jak się skończy lekcja to trzeba zawsze zasuwać krzesła. Że w jakiejś klasie trzeba się zachowywać i być cicho.

To znaczy, że mamy się uczyć i pisać bardzo, bardzo grzecznie i nie wolno dokuczać pani, jak pani coś pisze na przykład na tablicy dla dzieci. Albo pani woła do tablicy. I gada.

Z kolei w wywiadach, w których badaczka nie przywołała innej rzeczywistości niż przedszkolna, uczenie się jest definiowane przez dzieci przede wszystkim jako działanie odmienne od zabawy:

W zabawie można sobie klocki układać, a w uczeniu się nie.

Przecież wtedy [podczas zabawy] są zabawki, a w uczeniu się nie można się bawić zabawkami. 
Dzieci pozytywnie wartościują zabawę, ponieważ wówczas można robić, co się chce. Czyni to z niej nagrodę dla przedszkolaków zarówno za bycie grzecznym, jak i za uczenie się, które dla dzieci jest semantycznie tożsame z zajęciami, czyli organizacyjnie wyodrębnioną częścią dnia spędzanego w placówce:

Uczymy się jak pani powie, że sq zajęcia. Jak skończymy się uczyć, to możemy się pobawić. Bawimy się, kiedy skończymy pracę. Bawimy się, kiedy wszystko zjemy.

Jak szybko coś zrobię, to pani mówi-pobaw się.

Tak wyznaczony kontekst pojęcia prowadzi przedszkolaków do sformułowania konstatacji wartościującej: Jak się bawimy to jest fajnie, a w uczeniu się - nie. Zdają się ją wzmacniać także inne dziecięce skojarzenia z uczeniem się:

I na zajęciach trzeba stuchać się i być cicho, a na zabawie można być głośno.

Że w uczeniu się trzeba robić, co pani każe [...]. Jak się uczymy trzeba siedzieć grzecznie.

I na zajęciach trzeba robić kótko, bo pani każe.

Przedszkolaki, u których nie został zaktywizowany schemat szkoły, wpisują zatem zajęcia w kulturę ciszy i posłuszeństwa, podobnie jak czynili to z lekcją w szkole ich rówieśnicy badani inną wersją wywiadu. Przywołują też obawę przed karą lub oczekiwanie nagrody, uznając je za nieodłączny wymiar „,bycia posłusznym i grzecznym” w przedszkolu, nie tylko podczas zajęć:

Jak się stucha pani to się dostaje nagrody. Za grzeczne stuchanie i sprzątanie. Jak odniesiemy talerzyk.

Jak nie chcemy czegoś zrobić, to pani mówi, że nie pójdziemy na podwórko [...].

Jak dwie osoby chca to samo, a to jest dla jednej - to [...] pani zabiera.

Jak ktoś będzie szybko biegat w przedszkolu to może dostać karę.

Kara jest przez dzieci identyfikowana najczęściej z brakiem nagrody, zwłaszcza z przerwaniem zabawy i czasowym odosobnieniem. Są one także przekonane, że trzeba być „grzecznym przedszkolakiem”, by zostać pochwalonym, dostać drobną nagrodę materialną (np. balony, naklejki, ołówki, lizaki, klocki) lub:

dostać żólte buźki; dostać czerwona kropeczkę;

nie dostać smutnej buźki; nie dostawać czerwonych buziek i nie być wypisanym z przedszkola.

Znamienne jest, że owych symbolicznych „,buziek” przedszkolaki nie utożsamiają z ocenami, nawet gdy otrzymują je za wykonanie określonej pracy na zajęciach. Irytują się nawet, gdy prowadząca wywiad sugeruje takie skojarzenie, ponieważ ocenianie jest w ich mniemaniu zastrzeżone dla uczenia się w szkole: 
Bo w przedszkolu nie dostajemy ocen. Ale dostajemy tylko pieczątki.

Tylko w szkole. Ja nie, ale Czarek (starzy brat) dostaje, bo on się uczy.

Ostatnie z wypowiedzi wskazują, że ważnym wyróżnikiem szkolnego uczenia się poza doświadczanym już w przedszkolu powiązaniem go z przymusem, ciszą i podporządkowaniem - jest dla przedszkolaków otrzymywanie stopni. Stają się one także jednym $\mathrm{z}$ atrybutów bycia uczniem i tym samym współtworzą pole znaczeniowe następnej kategorii wyłonionej w analizie wywiadów.

\section{Być uczniem, być przedszkolakiem}

Obszar znaczeniowy tej kategorii jest kluczowy dla bezpośredniego identyfikowania przez dzieci roli społecznej ucznia, w którą muszą się wdrożyć. Przyjęcie na siebie obowiązku chodzenia do szkoły jest dla badanych przedszkolaków oczywiste, ale w ich mniemaniu wymaga tego, by dorosnać, jak uczeń i mieć lat siedem albo sześć, a ponadto wiąże się z dopełnieniem formalności: Ja myślę, że jak się zapiszę i będę miał 6 lat to pójdę do szkoty, do pierwszej klasy.

Wszystkie wypowiedzi dzieci, w których definiują one rolę ucznia, są wpisane w kontekst nakazu (trzeba) lub zakazu (nie można, nie wolno). Wszystkie też koncentrują się wokół szczegółowych zachowań decydujących o zaklasyfikowaniu danej jednostki do schematu kategorialnego (nie)grzecznego ucznia:

Trzeba być grzecznym za każdym razem. No i jeszcze trzeba się dobrze uczyć.

[...] stuchać pani, siedzieć cicho. [...] trzeba robić to, co pani każe.

Trzeba podnosić ręke wtedy, kiedy chce się zabrać głos.

Grzeczny to znaczy, że trzeba być dla pani mitym i nie wolno podczas lekcji krzyczeć, i nie wolno popychać [...]. I nie można gadać. I nie wolno jeść podczas lekcji. Nie wolno szczypać. Nie wolno gryźć. Nie można się kłócić. Nie wolno ciagnąć za włosy.

Ów specyficzny kodeks „bycia dobrym uczniem” zawiera w swym obszarze semantycznym wiele z tych zachowań, które przedszkolaki uznały za charakterystyczne dla sytuacji uczenia się, przeciwstawionej zabawie. Wprowadza to w jego zakres klimat dyscypliny i posłuszeństwa, a w ujęciu dzieci wiąże się z zasadnymi w gruncie rzeczy sankcjami za bycie niegrzecznym:

Jak się nieładnie zachowuje to się idzie do kata. To wtedy może trafić do nauczycielki lub nauczyciela. No może iść do dyrektora [...].

Jak ktoś jest niegrzeczny to dostanie od pani jedynkę albo dwójkę. To dostanie uwage. I minus może dostać.

Wróci do zerówki. 
W powyższym rejestrze szczególną uwagę zwraca zagrożenie „powrotem do zerówki”, które w kontekście wspomnianego już wymogu dorośnięcia do szkoły może oznaczać dla dziecka poważną deprecjację.

Natomiast egzekwowanie przestrzegania zasad dzieci pozostawiają nauczycielom. Wiązane z nimi znaczenia tworzą kolejną kategorię analizy.

\section{Nauczyciel w szkole, pani w przedszkolu}

W swoich wypowiedziach przedszkolaki używają wymiennie pojęć: nauczyciel i pani, dlatego trudno rozpatrywać ich znaczenie niezależnie od kontekstu, w jakim są wykorzystywane. Dzieci, u których został zaktywizowany schemat szkoły, odnotowują, że nauczyciel w szkole niekoniecznie musi być „panią”, ale mężczyzną, co nie budzi u nich szczególnych emocji. Znacznie bardziej znaczące dla nich jest, że czynności nauczyciela mają przede wszystkim wymiar dydaktyczny:

Żeby uczyt dzieci, żeby mówit, co trzeba zrobić. Żeby zadawać pytania; żeby pisać na tablicy. Żeby dat... dat prace dzieciom. [...] jeszcze po to, żeby dawać innym prace domowe. Albo sprawdza, czy dobrze sa zadania domowe zrobione. Żeby dawać minusa albo plusa. Żeby pilnować dzieci, żeby dbać o nie, żeby krzywda im się nie stała.

Jest też dla nich oczywiste, że bez nauczyciela uczenie się jest niemożliwe, a jego nieobecność może nieść ze sobą wyłącznie negatywne skutki dla uczenia się i dla zachowania:

Byśmy się niczego nie nauczyli. Dzieci by źle zrobity pracę, jak pani nie powie, co trzeba zrobić.

To by dziecko musiało same odgadywać, co ma robić. I by źle zrobiło i na pewno by dostat patę z minusem.

A jak nie było by nauczyciela to by dzieci robity, co chca [...]. No, bo by się wtedy nudzity. Dzieci by szalaty.

Wyznaczone w ten sposób pole znaczeniowe sytuuje nauczyciela w roli nadzorcy, osoby kierującej działaniami uczniów i decydującej o wykonywanej przez nich pracy, także za pomocą negatywnych ocen. Dzieci uznają go jednak za postać niezbędną do tego, by mogły się uczyć, choć są przekonane, że na pewno będzie „gorszą”, bo bardziej wymagającą i mniej miłą wersją ich ,pani” z przedszkola, będzie krzyczał i wystawiał za karę stopnie:

Bo mniej pracy zadaje, a w szkole więcej. Pani w szkole może dawać minusy albo plusy, a pani w przedszkolu nie.

Że pani nauczycielka jeszcze nie jest za bardzo mita w szkole. Będzie się inaczej zachowywała i będzie krzyczała. I daje patę z minusem. 
Można byłoby wnioskować, że przedszkolaki wytwarzają obraz nauczyciela, z którym spotkają się niebawem w szkole, przeciwstawiając go swoim dotychczasowym doświadczeniom edukacyjnym. Kwestię tę w nieco szerszym kontekście ukazują wypowiedzi dzieci, które w wywiadach mówiły wyłącznie o ,paniach” z przedszkola, nie odwołując się do czekającego ich pójścia do szkoły. Przypisują one „swoim” nauczycielkom kilka ról. Przede wszystkim ,pani” w przedszkolu jest rodzajem strażnika, który dba, by dzieci były grzeczne, nie robiły sobie krzywdy i dbały o porządek:

Pilnuje, żeby nikt nie bit nikogo. Albo nie popychat i drapat. A jak jesteśmy na podwórku, to stoi i patrzy; robi nam stop, jak biegamy po sali. No i jeszcze [sprawdza], czy jest ładnie $w$ sali $[\ldots]$.

Organizuje ona także dziecięce zabawy, a nawet, jak mówią przedszkolaki: [...] z nami uktada puzzle i podaje nam zabawki; [...] sprzata po naszych zabawach, bo my nie lubimy.

Tego szczególnego rodzaju wyręczającej opiekuńczości, połączonej z „miłym” nadzorem, dzieci doświadczają także na zajęciach, czyli podczas uczenia się. „Pani” nie tylko powie, co i jak zrobić, lecz nawet czasem wykona za nie pracę:

Wtedy pani mówi, co tam narysować. Pani podpowiada, gdzie i co, na która stronę trzeba wkleić. Ja nie umiałem wyciać serduszka dla mamy no i pani mi wycięła [...].

Jednak ta sama „pani” reaguje inaczej, gdy dzieci nie chcą wykonywać zadań lub czynią to - w jej mniemaniu - niestarannie lub źle. Wtedy staje się egzekutorką wymagań:

Wtedy pani mówi: Ale brzydka praca, musisz poprawić. Zmazuje i każe zrobić od nowa.

Pani się złości. Albo pani krzyczy. Pani głośno mówi.

Wtedy pani mówi, że trzeba zrobić, bo inaczej się pójdzie do maluchów.

Zestawienie ról przypisanych przez przedszkolaki znanej przez nich ,pani” i niepoznanemu bezpośrednio nauczycielowi w szkole, pozwala ustalić różnice znaczeniowe między schematami opisującymi obie postacie. Dzieci lokują działania nauczycielek przedszkola w określonych kontekstach sytuacyjnych. Są oswojone zarówno z „miłym” jak i „nieprzyjemnym wymiarem" nadzorowania, więc je akceptują, uznając za oczywiste nawet rygorystyczne wymaganie od nich bycia ,grzecznym przedszkolakiem” i wykonywania wyłącznie ,ładnych” prac.

Natomiast obraz nauczyciela w szkole jest dla przedszkolaków bardziej jednowymiarowy, bo bezkontekstowy. Jest dla nich jasne, że skoro w szkole mają się uczyć, tak jak na zajęciach w przedszkolu, to nauczyciel skupi się wyłącznie na tym, ale będzie wymagał więcej niż „pani”, bo ma władzę ukrytą w ocenianiu, co budzi u przedszkolaków respekt, ale też pewną nieufność i obawy. Mimo tego, są one gotowe zaakceptować nadrzędną pozycję nauczyciela, ponieważ są przeświadczone, że niczego się nie nauczą, jeśli ten nie będzie ich krok po kroku instruował. 


\section{Do jakiej szkoły?}

Zanim odpowiem na postawione we wstępie pytanie, chcę podkreślić, że badane przedszkolaki uznają szkołę za przestrzeń (roz)poznaną, a nawet w pewnym sensie oswojoną. Na owo ,przygotowanie do szkoły”, rozpatrywane w aspekcie społeczno-kulturowym, składają się liczne w gruncie rzeczy informacje, jakie dzieci uzyskały o niej z różnych źródeł: od osób znaczących i bliskich oraz z własnego doświadczenia. W efekcie nie podważają one konieczności pójścia do szkoły, a nawet traktują ten obowiązek jak rodzaj nobilitacji, do której trzeba dorosnąć, by stała się ich udziałem.

Wśród pojęć, które nabierają dla nich nowego, czyli „,szkolnego” znaczenia, dzieci wskazują między innymi: klasę i dwuosobowe ławki, zastępujące znaną im przedszkolną salę i sześcioosobowe stoliki; rozdzielane krótkimi przerwami lekcje, w które zamienią się „zajęcia”, a także nauczyciela, który nie musi być „panią”. Wiedzą też, że czekają na nich nowe doświadczenia, których mogą nabyć wyłącznie w szkole, gdzie codzienność jest zdominowana przez uczenie się, zawłaszczające też czas ,po lekcjach” i obejmujące obowiązkowe odrabianie prac domowych. W pewnym sensie czekają też na "prawdziwe" ocenianie za pomocą stopni, których w żadnym przypadku nie godzą się porównywać z otrzymywanymi w przedszkolu „buźkami” i kolorowymi kropkami.

Te atrybuty, swoiste dla dziecięcego widzenia szkoły, mają konkretny i wymierny charakter. Wyznaczają one kluczowe punkty sieci znaczeń nadawanych przez przedszkolaków edukacji szkolnej i stają się osią schematów poznawczych, które wykorzystają lub poddadzą weryfikacji później, czyli gdy staną się już uczniami.

Dzieci zdają sobie sprawę, że szkoła rządzi się swoimi prawami, wobec których muszą się jakoś określić. Przede wszystkim są przekonane, że idą do szkoły, by się „,dobrze uczyć". Wymaga to od nich wyrzeczeń, czyli zrezygnowania z zabawy lub jej zmarginalizowania do przerw między lekcjami, a ponadto oznacza, nie można będzie robić tego, co się chce, ale trzeba robić to, co pani każe. Przedszkolaki nie spodziewają się więc, by lekcje mogly być interesujące oraz przebiegać w swobodnej i twórczej atmosferze, w czym zresztą utwierdzają ich zajęcia w przedszkolu. Czas przebywania w klasie szkolnej jawi im się jako przestrzeń rytualnych czynności, ciszy i bezruchu, posłusznego wykonywania poleceń i samotnej pracy nad rozwiązywaniem trudnych zadań, w czym rozmowa z rówieśnikiem może tylko zaszkodzić. Ten klimat przymusu uczenia się jest wzmacniany koniecznością stałego zabiegania o dobry stopień lub pochwałę, a także potrzebą unikania kary, która może przybierać różną postać: począwszy od jedynki czy minusa, po dyscyplinującą rozmowę z dyrektorem lub kompromitujący powrót do zerówki.

Znamienne jest, że dzieci nie rozróżniają wyraźnie „dobrego uczenia się” i „bycia grzecznym”, scalając płynnie obydwa pojęcia w schemacie „dobrego ucznia”, który w ich ujęciu jest prawie tożsamy z kategorią , dobrego przedszkolaka”. Włączają w jego obszar semantyczny detaliczne wręcz skrypty zachowań pożądanych i nagannych, kryjących się za wyliczeniami tego, co „trzeba” i czego „nie wolno” robić w szkole, czyli co zadowala władzę, jaką jest nauczyciel. Lista zakazów i nakazów przywoływanych 
przez przedszkolaków jest imponująca, a na jej czele lokują się dosyć ogólnikowe i pozakontekstowe: „słuchanie pani za każdym razem” i „bycie cicho”. Natomiast bardziej zróżnicowane i konkretne okazują się przykłady zakazanych zachowań (typu bieganie, szczypanie, popychanie), które dzieci znają z osobistego doświadczenia i ich negatywnego wartościowania przez dorosłych.

Przedszkolaki nie mają wątpliwości, że do „dobrego uczenia się” i bycia „dobrym uczniem” jest im niezbędny (poza kilkoma przedmiotami i przyborami szkolnymi) przede wszystkim nauczyciel, który niekoniecznie musi być „dobry”, miły i pomocny. Dzieci tego zdają się od niego nie oczekiwać, bo identyfikują jego rolę wyłącznie z wypełnianiem funkcji dydaktycznych, w tym: kierowaniem każdym ich krokiem w uczeniu się, zadawaniem zadań domowych, kontrolowaniem i ocenianiem. Tak ukształtowany schemat, okrojony z „miłych” działań ,pani” w przedszkolu, sprawia, że nauczyciel w szkole staje się osobą, z którą spotkania można się obawiać. Połączenie tych dwóch wartościujących aspektów schematu poznawczego, w jaki zamknięty został nauczyciel: niezbędności oraz obawy, ugruntowuje u przedszkolaków, którzy chcą zostać uczniami, gotowość do podporządkowania się mu, ponieważ zna on lepiej od nich nakazy i zakazy szkoły, a ponadto może skutecznie egzekwować ich przestrzeganie za pomocą stopni.

Konkludując: analiza ukrytych w języku znaczeń nadawanych szkole przez przedszkolaków nie pozostawia złudzeń co do tego, do jakiej edukacji są one kulturowo i społecznie przygotowane. To szkoła ideologicznie wpisana w transmisję kulturową, osadzona w logice behawioralnych wzmocnień, pozytywnie wartościująca bezrefleksyjne posłuszeństwo oraz wykonywanie cudzych instrukcji jako strategię uczenia się, a w efekcie poddająca dzieci treningowi bezwolności i utrwalająca ich zewnątrzsterowność.

Tak sformułowana diagnoza nie odbiega od wyników badań tego obszaru prowadzonych w paradygmacie interpretatywnym, ale z wykorzystaniem innych metod (np. Karowowska-Struczyk 2011; Gawlicz 2014). Jej odczytanie zależy jednak od przyjętej perspektywy teoretycznej. Z pragmatycznego punktu widzenia można byłoby uznać, że przygotowanie przedszkolaków do przekroczenia pierwszego progu edukacyjnego jest adekwatne, ponieważ zostały one wyposażone w takie schematy poznawcze, które ułatwią im funkcjonowanie w nowych dla nich realiach. Możemy też jednak przyjąć, co jest rozwiązaniem znacznie mi bliższym, że rzeczywistość, w którą mają wkroczyć dzieci, jest w gruncie rzeczy „(anty)edukacją wczesnoszkolną” (Klus-Stańska 2014). Nie dostarczy im ona zatem inspiracji do innego niż odtwórcze uczenia się i nie wytworzy u nich poczucia sprawstwa (zob. Szyling 2015), pozwalającego rozsadzić przyciasne, wykreowane w przedszkolu schematy. W takim kontekście społeczno-kulturowy wymiar przygotowania do szkoły zamienia się w złożoną ze stereotypów klatkę, blokującą rozwój dziecka, z której tylko niektórym uda się wydostać. Problem w tym, że owo rozbijanie szkolnego schematu, pozbawione oparcia w atrakcyjnych alternatywnych wzorach, może też przybrać groteskowo wykrzywioną „gębę” Miętusa, bohatera „Ferdydurke”, czego przykład znaleźć można w wypowiedzi jednego z przedszkolaków: A mój brat się nie boi, bo ciagle dostaje paty. 


\section{Literatura}

Anusiewicz J. (1994), Lingwistyka kulturowa. Zarys problematyki. Wrocław, Wydawnictwo Uniwersytetu Wrocławskiego.

Appelt K. (2005), Wiek szkolny. Jak rozpoznać potencjat dziecka? W: A.I. Brzezińska (red.), Psychologiczne portrety czlowieka. Praktyczna psychologia rozwojowa. Gdańsk, Gdańskie Wydawnictwo Psychologiczne.

Flick U. (2011), Jakość w badaniach jakościowych. Warszawa, Wydawnictwo Naukowe PWN.

Gawlicz K. (2010), „Everything is dangerous”. Preschool teachers' discursive practices and children's positions. „Problemy Wczesnej Edukacji”, 2 (12).

Gawlicz K. (2014), Gotowi do podporządkowania się. Edukacja przedszkolna jako proces kształtowania zdezintegrowanych podmiotów. W: D. Klus-Stańska (red.), (Anty)edukacja wczesnoszkolna. Kraków, Oficyna Wydawnicza Impuls.

Gawlik K. (2012), Badania fokusowe. W: D. Jemielniak (red.), Badania jakościowe. Metody i narzędzia. Warszawa, Wydawnictwo Naukowe PWN.

Gopnik A. (2010), Dziecko filozofem. Co dziecięce umysty mówia nam o prawdzie, miłości oraz sensie życia. Warszawa, Prószyński i Ska.

Karowowska-Struczyk (2011), Reggio Emilia - pożądana filozofia i praktyka dla edukacji przedszkolnej. „Problemy Wczesnej Edukacji”, 2 (14).

Klimczuk A. (2013), Hipoteza Sapira-Whorfa-przegląd argumentów zwolenników i przeciwników. „Kultura-Społeczeństwo-Edukacja”, 1 (3).

Klus-Stańska D. (2004), Gdy szkoła zamyka okno na świat. W: D. Klus-Stańska (red.), Światy dziecięcych znaczeń. Warszawa, Wydawnictwo Akademickie „ŻAK”. s. 15-38.

Klus-Stańska D. (red.) (2014), (Anty)edukacja wczesnoszkolna. Kraków, Oficyna Wydawnicza Impuls.

Kvale S. (2010), Prowadzenie wywiadów. Warszawa, Wydawnictwo Naukowe PWN.

Lisek-Michalska J. (2013), Badania fokusowe: problemy metodologiczne i etyczne. Łódź, Wydawnictwo Uniwersytetu Łódzkiego.

Mendel M., Cieślak A. (2009), (P)rogi szkoły. W: D. Klus-Stańska, M. Szczepska-Pustkowska (red.), Pedagogika wczesnoszkolna - dyskursy, problemy, rozwiąania. Warszawa, Wydawnictwa Profesjonalne i Akademickie.

Stemplewska-Żakowicz K. (2002), Koncepcje narracyjnej tożsamości. W: J. Trzebiński (red.), Narracja jako sposób rozumienia świata. Gdańsk, Gdańskie Wydawnictwo Psychologiczne.

Szyling G. (2015), Uczniowskie poczucie sprawstwa a praktyki oceniania we wczesnej edukacji. „Studia Pedagogiczne”, LXVIII.

Trzebiński J. (2002), Narracyjne konstruowanie rzeczywistości. W: J. Trzebiński (red.), Narracja jako sposób rozumienia świata. Gdańsk, Gdańskie Wydawnictwo Psychologiczne.

Wiśniewska-Kin M. (2016), Dziecięce rozumienie świata - w poszukiwaniu uzasadnień postępowania badawczego. „Problemy Wczesnej Edukacji”, 1 (32).

Wojciszke B. (2000), Wiedza jednostki i sądy o świecie społecznym. W: J. Strelau (red.), Psychologia. Podręcznik akademicki. T. 3. Gdańsk, Gdańskie Wydawnictwo Psychologiczne.

Żytko M. (2014), Gotowość dzieci i gotowość szkoty do uczenia się. Rozważania wokót problematyki diagnozowania jakości wczesnej edukacji. „Ruch Pedagogiczny”, R. 85, 2. 